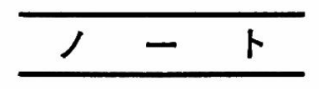

〔農化 第 39 巻, 第 2 号, p. 77 81，1965]

$$
\begin{gathered}
\text { カイガラムシの脂質に関する研究 (第 } 1 \text { 報)* } \\
\text { イセリヤカイガラムシの高級アルコールについて }
\end{gathered}
$$

向井克憲, 橋本 皓, 辻本恵洋 (大阪府立大学農学部農芸化学教室)

昭和 39 年 9 月 29 日受理

粕

言

外地からわが国へ侵入してきて土着したカイガラムシ は約 10 種といわれている(1).これらカイガラムシ類は, ミカン類など農作物の大害虫として有名である. それら のなかで, カタカイガラムシ科, ワタフキカイガラムシ 科などに属するすのには，その虫体に比し極めて多量の ロウ質物を分泌するすのがある：このロウ質物のために 殺虫剤散布などの撲隇作業上種々難点があり，この虫の 完全駆除対策は，今日における都市緑化の面にもゆゆし い問題をなげかけている.

日本産カイガラムシの化学的研究は 1932 8 年, 河 野(2)火上り行なわれたが, その後カイガラムシの脂質に 関する報告は見当らない，著者らは脂質成分の化学的研 究をさらにすすめようと思う．特に多量分泌されるロウ 質物の生合成機構掞よびその成分の生化学的役割化興味 を抱き本研究に着手した，本報に扬いては，まずその一 成分である高級アルコールを，イセリヤカイガラムシに ついて検索したのでその結果をここに報告する.

\section{1. イセリヤカイガラムシ}

\section{実 験 方 法}

イセリヤカイガラムシ (Icerya purchasi Maskel1)(3) はワタフキカイガラムシ科に属し, 雄は体長約 $2.7 \mathrm{~mm}$, 雌の成虫は体長 $5 \mathrm{~mm}$, 幅 $3 \mathrm{~mm}$ 内外, 楕円形, 暗橙黄 色で背面はいらじるしく隆起した黄白色の口ウ質物で厚 く覆われている. 著者らは 1963 年 5 月, 本学部構内和 よび堺市公園の樹木トペラに寄生しているものを採集し

* Studies on the Lipids of Coccids. Part I.

Higher Alcohols of Icerya purchasi Mask.

By Katsunori MUKAI, Akira HASHIMOTO and Yoshihiro TsUjImoto (University of Osaka Prefecture College of Agriculture, Taisen-cho, Sakai city, Osaka)
実験に用いた. 第 1

困はトベラに群棲し

ているイセリヤカイ ガラムシである.

2. 高級アルコー ルの分離方法

著者らの試みた供 試虫からの高級アル コールの分離は, 従 来(11)の蒸留拈よび 再結晶法に尿素付加 法, 薄層扣よびガス クロマトグラフ法な どを併用した方法で

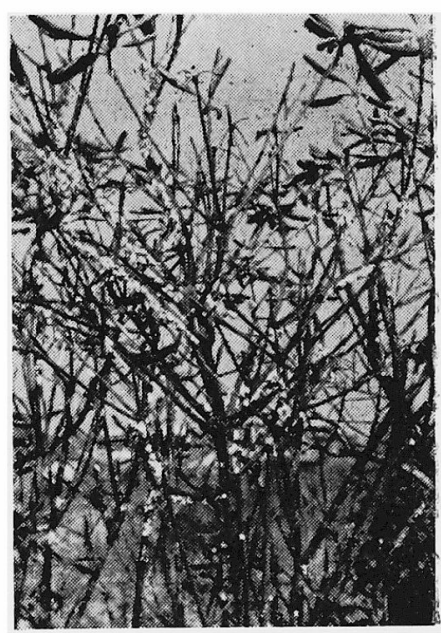

第1図トペラに群棲している イセリヤカイガラムシ

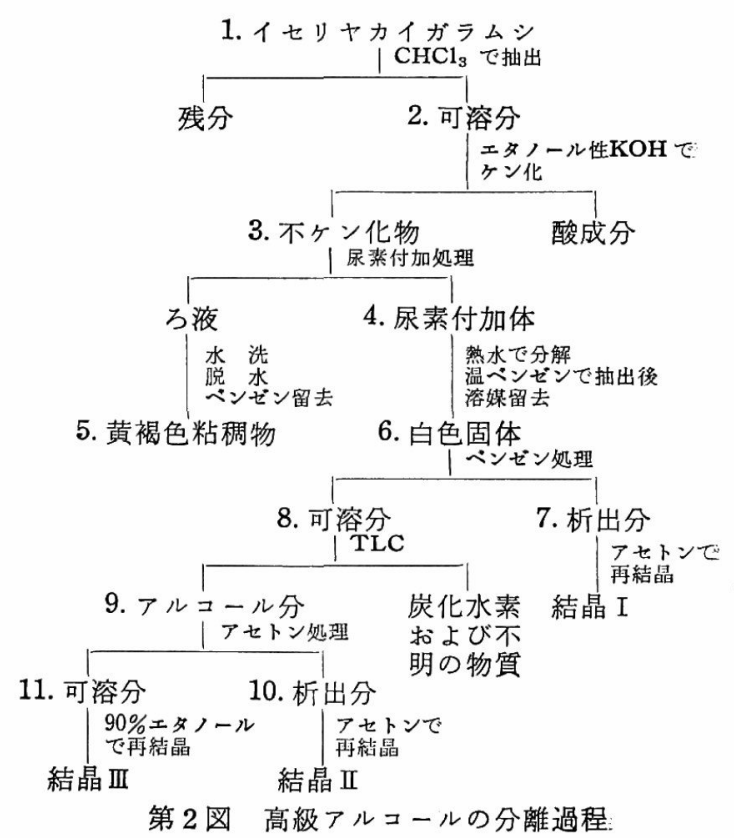

5. 黄褐色粘稠物 6. 白色固体

第 2 図高級アルコールの分離過程 
第 1 表 供試脂貿の性状

\begin{tabular}{|c|c|c|c|c|c|}
\hline $\begin{array}{c}\text { 外 } \\
\text { (観 } \\
\text { 常 温) }\end{array}$ & 酸価 & ケン化価 & 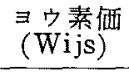 & $\begin{array}{l}\text { アセチ } \\
\text { ル価 } \\
\end{array}$ & $\begin{array}{l}\text { 不ヶン化物 } \\
\text { 含有率 }(\%) \\
\end{array}$ \\
\hline $\begin{array}{l}\text { 肯襡色の } \\
\text { 状 }\end{array}$ & 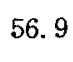 & 182.0 & 0.0 & 115.4 & S \\
\hline
\end{tabular}

ある、第2图はその分離過程を示したものである。な括

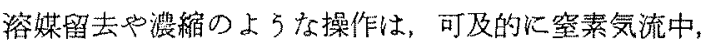
減王下で行なった。

(a) 脂質の抽出および不ヶン化物の分離：採集 2 〜3 時間後の供試虫 $120 \mathrm{~g}$ に $40 \mathrm{~g}$ の無水硫酸ナトリウ ムを加奌て乳鉢中で摩研した。そして大型りックスレー 抽出器を用いて，クロロホルムで 40 時間連続抽出を行 なった。溶媒を留去して第 1 表に示す性状の脂質 $26 \mathrm{~g}$ を得た。これを常法によりヶン化処理してエーテル抽出 を行ない，黄褐色固体状の不ヶン化物 $5.8 \mathrm{~g}$ を得た。

(b) 尿素付加処理：不ケン化物 $5 \mathrm{~g}$ Kベンゼン

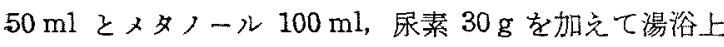
15 分加熱還流する。次に湯浴をとり惊ずして，マグネ

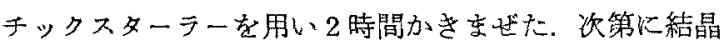
が析出したが，フラスコは密栓して冷蔵庫内 $\left(0 \sim 5^{\circ}\right)$ に 1夜静置したここうして生じた析出物心吸引濾别し， 。 ンゼンで 3 回洗い，白色の尿蒸付加体を得た。濾液部は 十分水洗し無水硫酸ナトリウムで脱水後ベンゼンを留去 L，黄襣色粘税物 $0.38 \mathrm{~g}$ を得た。 これを尿素非付加体 とした，付加体，非付加体についての以後の操作は実験 結果の項に扣いて速へる。

\section{3. 薄層クロマトグラフィー（TLC）}

既報 ${ }^{(4,5)}$ に準して行なった。装置は東洋科学産業製を 用い、メルク社製のシリカダルGを吸着剤として，プレ 一ト $(20 \times 20 \mathrm{~cm})$ に $250 \mu$ の厚さに展着させた. $110^{\circ}$ で 30 分活性化し，使用時まで乾燥㓩を入れた容器中に 保存した，展開溶媒はnーへキサンーエチルニーテル（7： $3 \mathrm{v} / \mathrm{v})$ を用い空温で約 15 分 $10 \mathrm{~cm}$ 展開した。顕色は

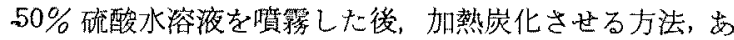
るいは $0.04 \%$ フルオレッセンナトリウム氷溶液を貲霧 してスボットの位置を確認した。な就高极アルコールを゙

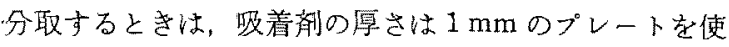
㛀した。

\section{4. ガスクロマトクラフィー (GLC)}

装置林柳本整ガスクロマトグラフ GCG 2 型を使用し

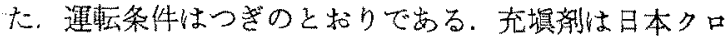
マト工業製の Diasolid S z担体とし, polydiethylene glycol succinate $10 \%$ 含浸したものでるるカカムム は内径 $6 \mathrm{~mm}$ ，長さ $1 \mathrm{~m}$ だ, 試料室温度は $300^{\circ}$ ，カラ ム温度は $220^{\circ}$ キャリアーガスはヘリウム，その出口の 流速は $20 \mathrm{ml} / \mathrm{min}$, bridge current は $170 \mathrm{~mA}$, recorder sens $2 \mathrm{mV}$ ，チャート速度は $5 \mathrm{~mm} /$ 分であった。 各成分ピークは標準飽和高級アルニールのアセテート $\left(\mathrm{C}_{12} \sim \mathrm{C}_{22}\right.$ 偶数炭素) を刘照としてその相対保持容量の 対数と炭素数との直線関俰 ${ }^{(6)}$ を用いて同定した。

5. 性状測定など

脂質の性状測定は常法(7)によったが，ヨり素洒はせミ クロ法 ${ }^{(8)}$ で測定した。 アルコールのアせチル化は Farquhar の方法 ${ }^{(9)}$ にり行ないアセテートを調櫘した。 た酶酸中で哭水ク口ム酸に上り酸化を行い脂肪酸を調篮 した。.結晶の融点の测定は，柳本徽量融点测定装置 MPS 2 型により行なった。赤外線吸収スペクトルは日立製

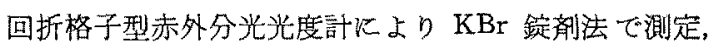
分子䤃の測定は Rast 法で行なった。

実験結果および考察

\section{1. $\mathrm{C}_{27}$ アルコールの分離}

前迹の尿菜什加体比水 $200 \mathrm{ml}$ を加文，加熱分解を行 ない，温ベンゼンで徹底的に抽出した。ベンゼン溶液は 水洗，無水硫酸ナトリウムで脱水，濾過した，濾別され た硫酸ナトリウムは乾㽞ベンゼンで 2 回洗い，その洗液 は先の滤液に合一した。ベンゼンを留去して白色固体 $3.4 \mathrm{~g}$ を得た。これを再び温べンゼン $50 \mathrm{ml}$ に溶解し， そのまま室温下で放膡すると白色の結晶が析出された。 滤别してアセトンで再結晶を行ないm. p. 81.0 81. $5^{\circ}$ の結晶 $\mathrm{I}$ を $0.4 \mathrm{~g}$ 得た。乙性状恃第 2 表に示すと物り で, 小山(10)，河野(11) らが既載のイボタセリルアルコ一

第 2 表 結晶I(イボタセリルアルコール)の性状

\begin{tabular}{|c|c|c|}
\hline & 測定做など & 文腩值など(10,11) \\
\hline 1. 融 点 $\left({ }^{\circ} \mathrm{C}\right)$ & $80.0 \sim 80.5$ & 80.5 \\
\hline 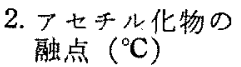 & $63.5 \sim 64.5$ & $64.0 \sim 65.0$ \\
\hline $\begin{array}{l}\text { 3. 酸化物(イ挍 } \\
\text { 七品ン酸) } \\
\text { 融点 }\left({ }^{\circ} \mathrm{C}\right)\end{array}$ & $81.5 \sim 82.0$ & $\left\{\begin{array}{l}82.0 \sim 82.5 \\
81.5 \sim 82.0\end{array}\right.$ \\
\hline 4.分 子 量 & 394 & 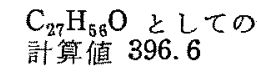 \\
\hline 5. 元素分析值 $(\%)$ & $\begin{array}{l}\text { C } 82.03 \\
\text { H } 14.25\end{array}$ & $\begin{array}{l}\mathrm{C}_{27} \mathrm{H}_{58} \mathrm{O} \mathrm{C}_{2} \text { ○の } \\
\text { 計算值 } \mathrm{C} 81.73 \\
\mathrm{H} 14.24\end{array}$ \\
\hline $\begin{array}{l}\text { 6. IR 줏 } \\
\text { (-OH band) }\end{array}$ & $\begin{array}{ll}3300, & 1060 \\
1070, & 1110 \mathrm{~cm}^{-1}\end{array}$ & $\begin{array}{l}\text { に極大吸收を示 } \\
\text { した }\end{array}$ \\
\hline $\begin{array}{l}\text { 7. ジナジウムオ } \\
\text { シン塩反応 }\end{array}$ & 陽 & \\
\hline
\end{tabular}




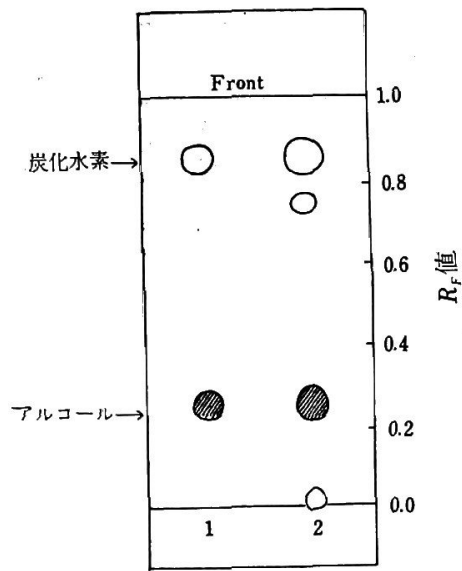

第 3 図 ヘンン゙ン可溶分の薄增 クロマトグラム

$1:$ 標品（ステアリルアルコール，エイコ サノール，ドュサノール，流動パラフ イン)

2 : 試 料

ルに一致した.

2. $\mathrm{C}_{26} \& \mathrm{C}_{24}$

アルコールの分離

第 2 図の分離工

程 8 (ペンゼン可

溶分）について,

TLCを行なった 結果は第 3 図に示 すとおりである。

すなわら, $R_{F}$ 值が $0.0,0.26,0.74$,

0.8504 成分に分

離することができ た。原点にとどま る物質と, 0.74 の

物質は不明である。 0

85の物質は同時に展開した流動パラフィンの $R_{F}$ 值に 一致するので炭化水素であると思われる．0.26の物質は， 明らかにバナジウムオキシン塩反応 ${ }^{(13)}$ が陽性であり, ルコールである. 同時に展開したステアリルアルコール や，ドコサノールもこの $R_{F}$ 値を示した. よってベンゼ ン可溶分について薄層の厚さ $1 \mathrm{~mm}$ のプレートを用いて TLC を行ない， $R_{F}$ 值 0.26 の物質を分取した.こ5し て得たアルコール分画は少量の温アセトンに溶解して室 温で放冷すれば白色結晶を析出した，滤別してアセトン で再結晶をくりかえし，結晶Iを $0.3 \mathrm{~g}$ 得た。アセトン 可溶分は冷蔵庫内に 1 夜放置すると白色結晶が析出した ので慮別し，90\%エタノールで再結晶をくりかえして結 晶正を $0.2 \mathrm{~g}$ 得た. 結晶II と而の性状は，それぞれ第 3 ，

第 3 表 結晶 II (ヘキサュサノール)の性状

1. 融 点 $\left({ }^{\circ} \mathrm{C}\right)$
2. アセチル化物の
融点 $\left({ }^{\circ} \mathrm{C}\right)$
3. 酸化物 (セロ $($ 融点
ン酸)

$\left({ }^{\circ} \mathrm{C}\right)$

4. 分子量

5. 元素分析値 $(\%)$

6. IR スペクトル (-OH band)

7. ペナシ்ムオキ シン塩反応

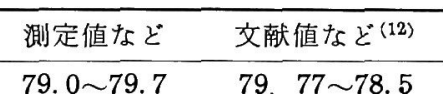

$60.6 \sim 61.8 \quad 60.0 \sim 60.1$

$82.5 \sim 83.5$

$83 \sim 84$

$82 \sim 82.5$

$\mathrm{C}_{26} \mathrm{H}_{54} \mathrm{O}$ としての 計算值 382.71

$\mathrm{C}_{26} \mathrm{H}_{54} \mathrm{O}$ としての 計算值 C 81.60 H 14.22 $\left.\begin{array}{l}3300,1060 \\ 1070,1110 \mathrm{~cm}^{-1}\end{array}\right\} \begin{aligned} & \text { に極大吸収を示 } \\ & \text { した }\end{aligned}$ 陽性
第 4 表 結晶（テトラュサノール)の性状

\begin{tabular}{|c|c|c|}
\hline & 測定值など & 文献值など(12) \\
\hline 1. 融 点 $\left({ }^{\circ} \mathrm{C}\right)$ & $75.0 \sim 76.0$ & $74 \sim 75, \quad 76.1$ \\
\hline $\begin{array}{l}\text { 2.アセチル化物の } \\
\text { 融点 }\left({ }^{\circ} \mathrm{C}\right)\end{array}$ & $55.5 \sim 56.0$ & $56 \sim 57, \quad 57$ \\
\hline $\begin{array}{l}\text { 3. 酸化物(リグノ } \\
\text { 七リソ酸) の融 } \\
\text { 点 }\left({ }^{\circ} \mathrm{C}\right)\end{array}$ & $83.0 \sim 84.0$ & 84.1 \\
\hline 4. 分子 量 & 357 & $\begin{array}{l}\mathrm{C}_{24} \mathrm{H}_{50} \mathrm{O} \text { としての } \\
\text { 計算值 } 354.66\end{array}$ \\
\hline 5. 元素分析値(\%) & $\begin{array}{l}\text { C } 80.88 \\
\text { Н } 14.19\end{array}$ & $\begin{array}{l}\mathrm{C}_{24} \mathrm{H}_{50} \mathrm{O} \text { とての } \\
\text { 計算值 } \mathrm{C} 81.27 \\
\mathrm{H} 14.21\end{array}$ \\
\hline $\begin{array}{l}\text { 6. IR スペクトル } \\
\text { (-OH band) }\end{array}$ & $\begin{array}{ll}3300, & 1060 \\
1070, & 1110 \mathrm{~cm}^{-1}\end{array}$ & $\left\{\begin{array}{l}\text { に極大吸収を示 } \\
\text { した }\end{array}\right.$ \\
\hline $\begin{array}{c}\text { 7. ジナジゥムオキ } \\
\text { シン塩反応 }\end{array}$ & & \\
\hline
\end{tabular}

4 表に示すとおりである。これらの諸成績からへキサコ サノール拉よ゙テトラコサノールとして同定した。

以上，河野がすでに結晶として分離した $\mathrm{C}_{27}, \mathrm{C}_{26}, \mathrm{C}_{24}$ の各アルコールを著者らす再確認することができた，河 野はさらに上記各アルコールの再結晶母液について減压 分留を行ない, その結果, $\mathrm{C}_{18}, \mathrm{C}_{16}, \mathrm{C}_{14}$ に相当するアル コールを認めているが精査するには至らなかった。そこ でこの点を検討した結果 $\mathrm{C}_{14}$ は検出できなかったが，新 たに $\mathrm{C}_{22}, \mathrm{C}_{20}$ のアルコールの存在することを知った。

3. $\mathrm{C}_{22}, \mathrm{C}_{20}, \mathrm{C}_{18}, \mathrm{C}_{16}$ アルコールの分離検出 先のテトラコサノールの分離を行なったさいの母液, すなわら泠アセトン可溶分について，溶媒を留去すれば 白色結晶が得られ，その融点は 72.6〜 75. $9^{\circ}$ を示した. アセチル化を行ない，TLCで検した結果は第 4 図のと

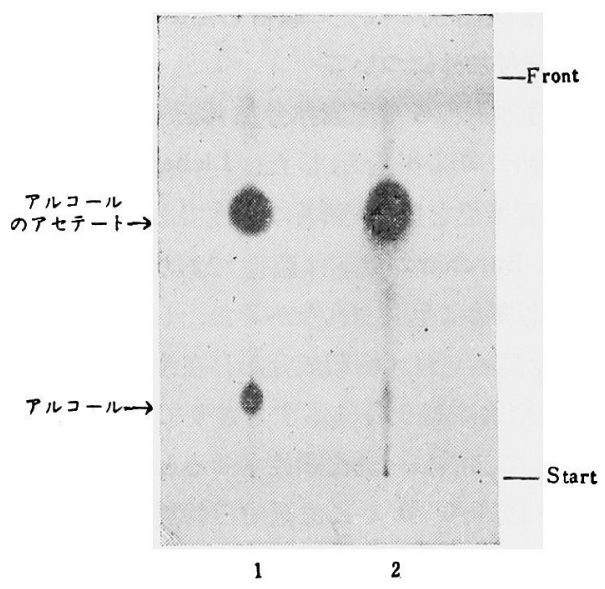

第 4 四ア七チル化物の薄凮クロマトグラム $1:$ 骤品(ステアリルアルコール，ステアリル アルコールのアセテート) $2:$ 倵料 

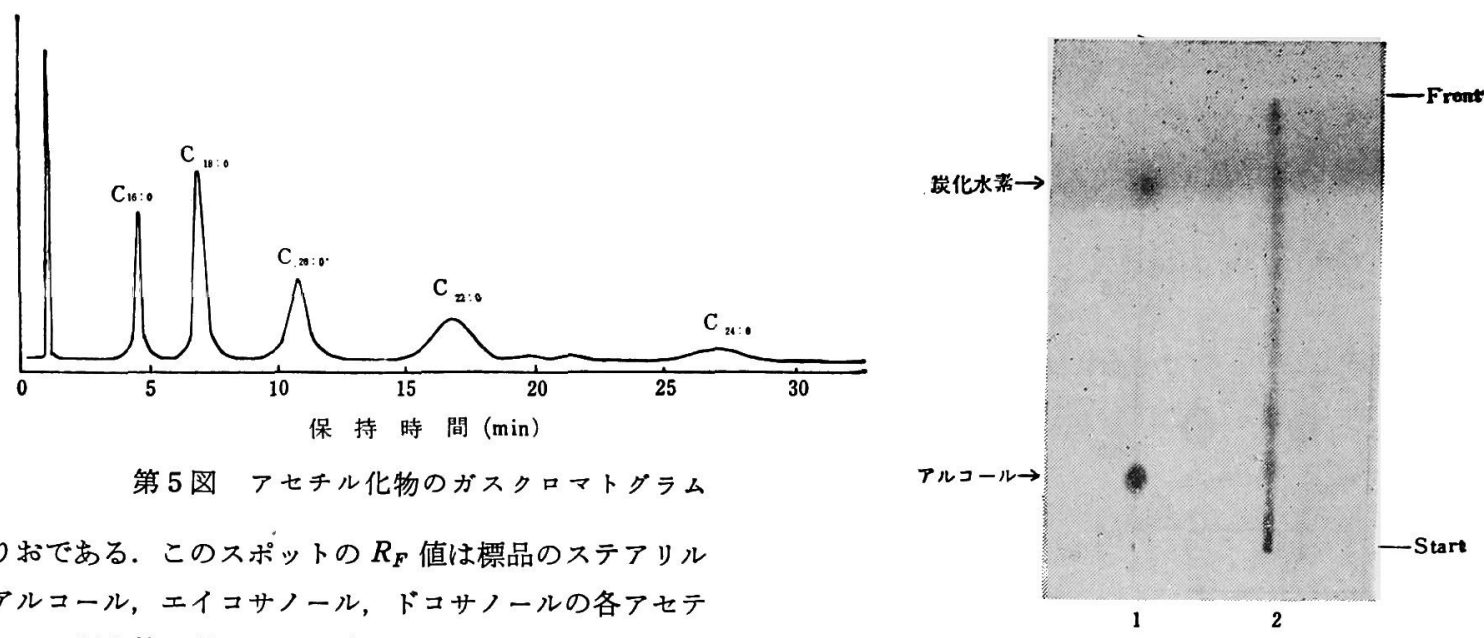

り淿であ. このスポットの $R_{F}$ 值は標品のステフリル アルコール，エイコサノール，ドコサノールの各アセテ 一トの混合物の $R_{F}$ 値に一致した. 第 5 図はアセチル化 物のガスクロマトグラムである. $\mathrm{C}_{22}, \mathrm{C}_{20}, \mathrm{C}_{18}, \mathrm{C}_{16}$ の各 アルコールを分離検出することができた。

以上のように, 分離過程に TLC と GLCを併用して, 比較的少量の脂質から第 5 図の 4 種と前記の $\mathrm{C}_{27}, \mathrm{C}_{26}$, $\mathrm{C}_{24}$ の 3 種を分離検出することができた. このように既 報で著者ら ${ }^{(5)}$ が報告した TLCによる不ヶン化物からの 高級アルコールの分画法は, カイガラムシのような虫体 の小さいるのを採集し，それを分析していく上におい て, はなはだ有用と思われる. 一方, 高級アルニールの GLC 分析に関し, $\mathrm{C}_{24}$ 以上についての報告は目下のとこ ろ見当らない. 他のカイガラムシに比べて多種の高級ア ルコール成分を含む(14) イセリヤカイガラムシのアルコ ール組成は,今回の実験では求めることができなかった。 これについては今後， $\mathrm{C}_{27}, \mathrm{C}_{26}$ 等の $\mathrm{GLC}$ による分離条 件を十分検討の上, 別の機会に報告したいと考えている.

\section{4. 尿素非付加体について}

第 2 図の分離過程 5 の尿素非付加体は黄褐色粘稠物 で, ヨウ素価は 203.8 を示した. Liebermann-Storch 反応 ${ }^{(15)}$ は濃青紫色を呈し, 顕著に陽性であった。しかし Liebermann-Burchard 反応は陰性であり，またジギト ニンによる沈殿物は生成されなかった. したがってステ リンの存在は認められず樹脂成分が存在するるのといえ る.TLC の結果は第 6 図に示すと扣りであった５0\% 硫酸を貲霧して加熱し, 炭化顕色させるときの観察から おとらく $R_{F}$ 值 $0.0 \sim 0.2$ に位置する物質が樹脂成分と 思われる. 一方 $R_{F}$ 值 0.26 に位置するスポットは, 同 じく硫酸噴霧後加熱すれば，同時に展開した標品のステ アリルアルコールよりもすみやかに炭化顕色した. よっ て上記のヨウ素価からして技そらく不飽和高級アルコー

ルの存在も予想される. しかし TLCにより分取したア ルコール分画は，試料として僅少のため今回は精査する に至らなかった。

要 約

イセリヤカイガラムシ脂質の高級アルコールについて 検索した. すなわら, その脂質のクロロホルム可溶画分 をケン化後尿素付加体をつくり，これを熱水分解後， 一 ンゼン，アセトンおよび $90 \%$ エタノールなどによる浴 剤分別結晶法扎よび薄層クロマトグラフィーによって, $\mathrm{C}_{27} ， \mathrm{C}_{26}$ および $\mathrm{C}_{24}$ アルコールをそれぞれ結晶として得 た、また薄層およびガスクロマトグラフィーの併用によ って結晶母液中より低級な $\mathrm{C}_{22}, \mathrm{C}_{20}, \mathrm{C}_{18}, \mathrm{C}_{16}$ などのて ルコールが存在することを見出した.

本研究を行5に当り，イセリヤカイガラムシの同定を していただいた本学部農業昆虫学教室六浦 晃博士, ま たドコサノールをご提供くださった資源技術試験所鈴木 正臣博士に梁く感謝いたします。な招本報告は昭和 39" 年 4 月 25 日，日本農芸化学会関西支部例会において発: 表した.

（1）宮下和喜： 自然，18，106 (1963).

（2）河野通男： 本誌， 8，1150（1932）；本誌, 15, 177 (1938)

（3）石原 保：系統農業昆虫学, 盖賢堂, p. 159 (1963).

(4) H.K. Mangold : J. Am. Oil Chemists' Soc., 38, 708 (1961).

（5）橋本 皓, 向井克憲：油化学, 12,613(1963).

（6）森幹男，岩切泰子，小沢昭夫，柴田繁子: 
日水産，30, 161 (1964).

（7）油脂分析試験法，理化書院 (1956).

(8) R.P.A.Sims, B.Stone : J.Am. Oil Chemists Soc., 33, 287 (1956).

(9) J. W. Farquhar : J. Lipid Research, 3, 21 (1962).

(10) 小山亮清：日化，54，348 (1934).

（11）河野通男： 本誌，11，647 (1935).
(12) Arbin H. Warth : "The Chemistry and Technology of Waxes", p. 21 (1960).

(13) F. Feigl : "Spot Test's in Organic Analysis", p. $184(1960)$.

（14）河野通男： 本誌，14，626 (1938).

（15）上野誠一，岡村善策：油脂赛験法， p. 251 (1950). 